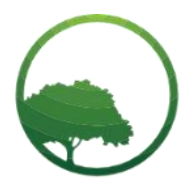

Research in Business \& Social Science

IJRBS VOL 10 NO 7 ISSN: 2147-4478

\title{
Investigating the challenges for the development of independent retailers in South Africa
}

\author{
K.Mercy Makhitha ${ }^{(a)}$ (D) Brian Soke $e^{(b)}$ \\ (a) Professor(s), Department of marketing and Retail Management, Unisa, South Africa
}

\author{
A R T ICLE INFO \\ Article history: \\ Received 12 August 2021 \\ Received in rev. form 25 Sep. 2021 \\ Accepted 27 Sept 2021 \\ Keywords: \\ Informal independent retailers, \\ challenges, SME operations, South \\ Africa \\ JEL Classification: \\ $\mathrm{O} 15$
}

\begin{abstract}
A B S T R A C T
Independent retailers face many challenges that influence their growth and development. Independent retailers are small businesses facing competition from major retailers in South Africa (SA) that have penetrated the townships and rural areas. The purpose of the study was to investigate the challenges that influence the development of independent retailers in SA. A survey was conducted among small independent retailers in SA. The convenience sampling method was adopted for the study due to inaccessibility of a database on independent retailers in SA. Existing literature was used to design a questionnaire, targeted at small independent retailers, to investigate the challenges that influence their business performance. The findings of the study revealed that finance and marketing are the major challenges influencing the operations of small, independent retailers. Business-related challenges are the least challenging aspects for small independent retailers in SA. Independent retailers need to manage their businesses appropriately in order to survive and sustain their businesses. Independent retailers buy products from wholesalers while a few of them buy directly from manufacturers.
\end{abstract}

(C) 2021 by the authors. Licensee SSBFNET, Istanbul, Turkey. This article is an open access article distributed under the terms and conditions of the Creative Commons Attribution (CC BY) license (http://creativecommons.org/licenses/by/4.0/).

\section{Introduction}

Independent retailers in South Africa (SA) face many challenges. These challenges have influenced their survival and growth. A small number of major retailers that create an environment of severe competitive pressure for small independent retailers dominates the retail market in SA. These major retailers have also increased their market penetration in SA by extending their services to the townships and rural areas and they have increased their marketing efforts through brand promotions and advertising (Durham, 2011). The penetration of large retailers into the townships and rural areas has led to a decrease in the number of small independent retailers and, at the same time, some of these small retailers have experienced a decline in profitability (Department of Economic Development, 2015). Pre-1994, large retailers were traditionally reluctant to penetrate the markets in the townships and rural areas; however, this has since changed due to a focus on creating economic hubs in these areas and, consequently, shopping centre developments have mushroomed in the township areas especially. Increasingly, independent retailers are losing customers to major retailers in SA, since customers are spending less at independent stores compared to large retailers (Durham, 2011).

The retail market in SA constitutes the formal and informal sectors. The informal sector consists mainly of spaza shops, hawkers and street vendors, which are found in townships and rural areas. This market is largely served by the wholesale market, since most of the goods they sell are sourced from the wholesalers and sometimes, from the supermarkets. The informal market specialises mainly in foodstuffs, which constitute $22.5 \%$ of the market. Over $81 \%$ of households in SA are supplied by the informal market. The informal and independent retail market grew 45\%, from R79.5 billion in 2010 to an estimated R115.6 billion in 2013 (Sustainalytics, 2012; W\&R Seta, 2011).

Independent retailers target low-income consumers and this type of enterprise is a means through which small suppliers can enter into the supply chain (Makhitha, 2017). According to Das Nair and Dube (2015), there are over 100000 informal stores in SA, which

* Corresponding author. ORCID ID: 0000-0001-5040-3826

(C) 2021by the authors. Hosting by SSBFNET. Peer review under responsibility of Center for Strategic Studies in Business and Finance.

https://doi.org/10.20525/ijrbs.v10i7.1226 
stock fast moving items and operate at very low profit margins. Independent retailers emerged as a result of a policy of segregation that demarcated shopping and residential zones for minority citizens, to the exclusion of the black majority citizens, which created opportunities for black entrepreneurs to establish businesses to serve their communities (Chikwekwe, 2015).

Independent retailers appeal to consumers due to their lower prices, personalised customer service, credit facilities, availability of specialist products, location advantages and convenience (Das Nair, 2016). However, a study conducted by the Italian Trade Agency (2013) reported that more consumers shop at Checkers, followed by Pick n Pay, the spaza shops (informal retail outlets) and Spar. Consumers are still buying from independent retailers to replenish their grocery items, despite the rapid decline in consumers purchasing from independent retailers (Strydom, 2012). As reported in the Business Day (2017), the number of consumers who shop at the independent retailers grew from $45 \%$ in 2015 to $54 \%$ in 2016 and independent retailers' sales grew 13.4\% over a year to March 2017. However, there are certain challenges that inhibit independent retailers from achieving success, and also attracting and keeping consumers, which have influenced independent retailers' success.

Independent retailers in SA are facing severe pressure from resourceful large retailers that are entering and expanding their markets in the townships and rural areas. The large retailers' penetration of the townships and rural areas has influenced consumer behaviour, since consumers have reduced their spending at independent retailers (Durham, 2011). It is therefore imperative that independent retailers revisit and re-evaluate their business and marketing strategies and find solutions to ensure their survival. For independent retailers to successfully formulate effective and efficient business and marketing strategies, they must identify the challenges they are confronted with in the market, besides the threat posed by large retailers.

There is an increasing trend of foreign-owned independent retailers entering the market, which is also placing severe competitive pressure on SA-owned independent retailers. The foreign-owned independent retailers sell products cheaper and use price discounting as a strategy to capture the market from existing stores, which SA-owned independent retailers are unable to do. SA-owned independent retailers can be considered survivalist micro enterprises due to the size of their businesses and the revenue they generate (Liedeman, Charman, Piper, \& Peterson, 2013). Determining which challenges impact on the success of SA-owned independent retailers would help them to improve the performance of their businesses.

The objective of this study is therefore to determine the challenges that influence the development of independent retailers in SA. The study will also determine if finance-, marketing-, supplier- and business-related challenges differ across levels of education, years of operation, source of supply and number of suppliers.

\section{Literature Review}

\section{Theoretical and Conceptual Background}

\section{The importance of independent retailers in SA}

Independent retailers in SA can be categorised in the Department of Trade and Industry's (DTI) definitions of small, medium and micro enterprises (SMMEs), as outlined by the National Strategy for Small Business Development (DTI, 1996; Makhitha, 2016). They are businesses that are privately owned and do not belong to any large chain store (W\&R Seta, 2011). Since most independent retailers specialise in food and groceries, independent retailing represents an alternative model to enter the supermarket industry, as opposed to the traditional supermarket chain model (Das Nair \& Dube, 2015).

As SMMEs, independent retailers fulfil a number of roles, ranging from that of a poverty alleviation and employment creation tool to contributing to the country's international competitiveness (Nieman, Hough, \& Nieuwenhuizen, 2003; Ciubotariu 2013). Independent retailers play a vital role in the economy of any country, developed or developing, through their contributions to the economic developmental agenda of states (Muhammed, Char, Yasoa, \& Hassan, 2010). SMMEs further improve and develop the standard of living in South Africa by playing a role in tackling socioeconomic challenges such as low economic growth, high unemployment and the unsatisfactory levels of poverty in South Africa, particularly in the rural areas (Lekhanya, 2010). SMMEs generally account for almost $91 \%$ of businesses and contribute $60 \%$ towards the country's employment and 51 to $57 \%$ towards the gross domestic product (GDP) (Kongolo, 2010). However, 70 to 80\% of SMMEs fail within three years (Van Eeden, Viviers, \& Venter, 2003) and it is, therefore, important to identify the challenges that small independent retailers are facing in SA.

\section{Independent retailers and challenges}

Independent retailers face many challenges that influence their growth and survival, despite various government initiatives and support structures that have been established to support small businesses, including independent retailers. Existing studies have identified a number of challenges that affect the growth and survival of small businesses.

Although existing studies have sought to identify challenges influencing SMEs, they have not led to a permanent solution to such challenges. The most common challenges for small businesses are that they are small and they are owner managed. According to Hogarth-Scott, Watson and Wilson (1996), owner-managers are responsible for all business activities involving, among other things, management of the business, purchasing, production, human resources, sales and marketing, and financial management, which affects their ability to perform these functions efficiently and effectively. Mutandwa, Taremwa and Tubanambazi (2015), on the other hand, 
highlight capacity in respect of marketing and entrepreneurial skills, the working environment and the availability of materials and infrastructure as factors that influence independent retailers.

Finance has been cited in many studies as a major constraint for independent retailers (Wanjohi \& Mugambi, 2017). Wiklund and Shepherd (2005) found that higher small business performance is associated with greater access to financial capital, which implies that independent retailers that do not have access to finance are doomed to fail (Das Nair \& Dube, 2015). Lack of and limited financial resources make it hard for independent retailers to function well, giving rise to a lot of challenges (Cruz-Cunha \& Varajao, 2011; Leboea, 2017).

A study conducted by Makhitha (2016) showed that marketing-related challenges are also major challenges compared to financerelated challenges. Van Scheers (2011) found that SMEs face challenges with regard to the marketing of their products - they show a lack of understanding of the market and cannot perform market needs analyses. Phokwane (2020) found lack of marketing research to be a major challenge for SMEs in that they are unable to segment the market and cannot successfully and effectively market their products. Similarly, another study found that SMMEs face challenges with respect to the marketing of products, locality and lack of knowledge of the market (Radipere \& Van Scheers, 2005). Other marketing-related challenges include lack of marketing knowledge and expertise and limited use of marketing strategies (Lekhanya, 2010).

According to Liedeman et al. (2013), foreign-owned spaza shops are more competitive than SA-owned spaza shops since foreignowned shops offer cheaper products and are better stocked than SA-owned shops. Foreign-owned spaza shops are also involved in group purchasing to secure discounts and operational economies of scale, which makes them more competitive (Liedeman et al., 2013).

Other challenges that independent retailers face are business-related challenges, such as lack of effective management; lack of entrepreneurial, managerial and technical skills; failure to get credit from both suppliers and banks (Phokwane, 2020; Grimsholm \& Poblete, 2009; Phaladi \& Thwala, 2008); supply chain inefficiency; failure to embark on extensive marketing practices due to lack of finance (Chiliya, Herbst \& Roberts-Lombard, 2009; Brint, Cant, \& Ligthelm, 2003); inability to prepare a business plan; ineffectiveness in acquiring and retaining employees ( Phokwane, 2020; Makhubela, 2019); and lack of time, resources, technology or expertise to research and develop new business ideas and innovations (Lussier \& Hyder, 2016). The selection of the appropriate location for a small independent retailer could make or break the business (Mariotti \& Glackin, 2012). Independent retailers must determine whether location would be suitable for their customers' needs and the business's needs (Khosa \& Kalitanyi, 2014 ).

According to Das Nair and Dube (2015), small independent retailers' owners' lack business management skills and retail capabilities. They are unable to offer the supplementary service of offering a wide assortment of other, non-food goods, that is to say, a variety of products on sale together in a convenient setting and location, with a focus on quality, service, "one-stop" shopping and an overall shopping experience (Basker \& Noel, 2013) that supermarkets do, which creates a competitive disadvantage. Supermarkets have the capacity and the resources to invest in logistics, distribution centres, networks and inventory maintenance, which is out of reach for independent retailers (Das Nair \& Chisoro, 2015).

Independent retailers are also affected by supplier-related challenges such lack of economies of scale. Moreover, they lack good retail logistics, centralised procurement, consolidated distribution and good inventory management, which are inherent in large retailers (Reardon et al., 2003). Independent retailers are also faced with limited resources, a small number of products in stock, few customers and low volume (Makhitha, 2016). Large retail chains are able to provide a wide range of products and services at a lower price and to provide goods and services to low-income consumers (Das Nair \& Chisoro, 2015), which independent retailers are unable to match (Liedeman et al., 2013; Ravhugoni \& Ngobese, 2010). Furthermore, independent retailers source products from supermarkets, which disadvantages them since they are unable to source goods at competitive prices compared to large retail chains that source goods directly from manufacturers (Global Agricultural Information Network, 2011). Independent retailers also do not belong to buying groups that could source products on their behalf, which further disadvantages them (Ravhugoni \& Ngobese, 2010; W\&R Seta, 2011).

\section{Empirical Review and Hypothesis Development}

Eijdenberg and Borner (2017) investigated the factors that influence the operations of small businesses and found that operations experience and age have an impact on the performance of informal businesses, while gender, education and support from family also played an important role. Educational level was found to influence their ability to source finance from banks (Teixeira \& Sharifu, 2017). Various studies reported that operations experience influences the operations of businesses, which in turn determines how independent retailers manage the challenges they face (Afande, 2015; Soke, 2014) Makhubela (2019) and Phokwane (2020) found that the challenges that independent retailers face differ across years of operations experience.

Factors such as gender, age and level of education must be reflected when marketing communication strategies are implemented (Breytenbach, 2014). Makhitha (2019) investigated the impact of educational level on relationship marketing practices of independent retailers. The results indicated that educational level has a significant impact on independent retailers, which could mean that the challenges that influence independent retailers could differ across levels of education. Makhitha (2017a) and Makhitha (2020) also found education to influence the operations of independent retailers. The relationship marketing practices of independent retailers was found to influence the performance of the retailers (Makhitha, 2017b) This implies that independent retailers with a large number 
of suppliers perform less compared to those with few suppliers since they tend to develop long-term relationships that have a positive impact on their operations. Therefore, the number of suppliers influences the operations of independent retailers. The level of service provided by suppliers also has an impact on the performance of independent retailers (Craig, DeHoratius, \& Raman, 2016). Against the above background, the following hypotheses were formulated:

$\mathrm{H}_{1}$ There are significant differences between demographic variables such as level of education, years of business operation and number of suppliers of independent retailers with respect to financial challenges they experience.

$\mathrm{H}_{2}$ There are significant differences between demographic variables such as level of education, years of business operation and number of suppliers of independent retailers with respect to marketing challenges the experience.

$\mathrm{H}_{3}$ There are significant differences between demographic variables such as level of education, years of business operation and number of suppliers of independent retailers with respect to supplier-related challenges they experience.

$\mathrm{H}_{4}$ There are significant differences between demographic variables such as level of education, years of business operation and number of suppliers of independent retailers with respect to business challenges they experience.

\section{Research and Methodology}

\section{Study design}

The study targeted small, informal, independent retailers in SA. The informal retailers in Soweto, Johannesburg, were targeted specifically for this study. Johannesburg is the largest city in SA, while Soweto, an amalgamation of several different townships, is the largest township in Johannesburg. Over 43\% of the population of the City of Johannesburg lived in Soweto in 2004 (Ligthelm, 2008). The sample included informal retailers such as spaza shops, street vendors and general dealers. Interviews were conducted with the owners or managers of the businesses. A convenience sampling method was adopted, owing to a lack of access to a database of independent retailers in Johannesburg, SA. Convenience sampling is a sampling method that allows a researcher to choose whoever is available at a lower cost (Cooper \& Schindler, 2006).

Data was collected using two fieldworkers, who were trained prior to data collection. The questionnaire was pre-tested with 20 independent retailers. Feedback from the pilot test was used to adapt the wording of the questionnaire.

\section{Sample design}

A self-completion questionnaire was used. The fieldworkers distributed the questionnaires to the independent retailers, who were responsible for completing the questionnaire. Two hundred (200) questionnaires were distributed; however, only 116 of them were completed, yielding a 58\% response rate. This was due to the lack of willingness from independent retailers to participate in the study.

\section{Questionnaire construction}

The questionnaire was designed using literature on challenges and constraints in small businesses and retailers (Bataineh et al., 2015; Chinomona \& Pooe, 2013; Claro \& Claro, 2010; Hsu et al., 2008; Kannan \& Tan, 2006; Villena et al.,2011). There were 2222 "yes" or "no" dichotomous questionnaire items in the questionnaire measuring challenges facing independent retailers in SA. Data were analysed using SPSS version 25 . Respondents were given an opportunity to add more challenges by adding the item to the category, "other- please specify", on the questionnaire. There were five demographic questions listed on the questionnaire.

\section{Data collection and data analysis}

Data was analysed using SPSS version 23. Descriptive statistics were conducted, and the results are reported and discussed in the next section. The frequencies and percentages of the challenges were determined during statistical analysis. Descriptive statistics were used, and ANOVA tests (statistical analyses used to test for differences between two means or more group means (Sudman \& Blair, 1998) were conducted. A significant ANOVA result would indicate that at least one pair of means differ significantly, therefore post hoc tests can indicate which pair(s) differ(s) significantly (Hair, Black, Babin, \& Anderson, 2010).

\section{Results And Findings}

\section{Descriptive statistics}

As can be seen in table 1 below, the majority of respondents are between the ages of 30 and 40 (40.5\%, $n=47)$, followed by those between 25 and 29 years old $(223.3 \%, \mathrm{n}=27)$. Just over two-thirds $(67.9 \%, \mathrm{n}=76)$ of the respondents are male. Almost half of the respondents manage their own businesses $(46.9 \%, n=53)$, followed by managers $(38.1 \%, n=43)$, while $15.0 \%(n=17)$ indicated that they are neither the owner nor the manager of the business.

More than one-third of the businesses have been in operation for more than 10 years $(34.2 \%, \mathrm{n}=38)$ and $58.5 \%$ have matured beyond 5 years $(58.5 \%, \mathrm{n}=65)$. The largest proportion of the respondents have completed Grade 12 or matric $(42.9 \%, \mathrm{n}=48)$, followed by those who have a diploma or certificate $(28.6 \%, \mathrm{n}=32)$. 
Table 1: Demographics of the respondents

\begin{tabular}{|c|c|c|c|}
\hline & & Frequency & Percentage $\%$ \\
\hline \multirow[t]{6}{*}{ Age } & $20-24$ years & 5 & 4.3 \\
\hline & $25-29$ years & 27 & 23.3 \\
\hline & $30-40$ years & 47 & 40.5 \\
\hline & $41-50$ years & 15 & 12.9 \\
\hline & $51-59$ years & 11 & 9.5 \\
\hline & $60+$ years & 10 & 8.6 \\
\hline \multirow[t]{2}{*}{ Missing } & & 1 & 0.9 \\
\hline & TOTAL & 116 & $100 \%$ \\
\hline \multirow[t]{2}{*}{ Gender } & Male & 76 & 65.5 \\
\hline & Female & 36 & 31.0 \\
\hline \multirow[t]{2}{*}{ Missing } & & 4 & 3.4 \\
\hline & TOTAL & 116 & $100 \%$ \\
\hline \multirow[t]{3}{*}{ Position } & Owner-manager & 53 & 45.7 \\
\hline & Manager & 43 & 37.1 \\
\hline & Other (please specify) & 17 & 14.7 \\
\hline \multirow[t]{2}{*}{ Missing } & & 3 & 2.6 \\
\hline & TOTAL & 116 & $100 \%$ \\
\hline \multirow[t]{5}{*}{ Business operation } & Less than 1 year & 7 & 6.0 \\
\hline & Between 1 and 3 years & 21 & 18.1 \\
\hline & Between 3 and 5 years & 18 & 15.5 \\
\hline & Between 5 and 10 years & 27 & 23.3 \\
\hline & Over 10 years & 38 & 32.8 \\
\hline \multirow[t]{2}{*}{ Missing } & & 5 & 4.3 \\
\hline & TOTAL & 116 & $100 \%$ \\
\hline \multirow[t]{5}{*}{ Level of education } & Less than 1 year & 7 & 6.0 \\
\hline & Between 1 and 3 years & 21 & 18.1 \\
\hline & Between 3 and 5 years & 18 & 15.5 \\
\hline & Between 5 and 10 years & 27 & 23.3 \\
\hline & Over 10 years & 38 & 32.8 \\
\hline \multirow[t]{2}{*}{ Missing } & & 4 & $3.4 \%$ \\
\hline & TOTAL & 116 & $100 \%$ \\
\hline
\end{tabular}

Table 2 shows the source of supply, the number of suppliers and support that independent retailer receive from their suppliers. As the table indicates, independent retailers source their merchandise from the wholesalers (74\%), followed by sourcing directly from the manufacturers (18\%). Independent retailers receive support from their suppliers which include, charging independent retailers affordable prices, giving them price discounts and supplying them with promotional materials. It is important to note that the questions on source of supply and support from suppliers were multiple-response questions.

Table 2: Source of supply

\begin{tabular}{llll}
\hline & & Frequency & Percentage $\%$ \\
\hline *Source of supply & Buy direct from the wholesalers & 93 & $74.4 \%$ \\
\hline & Buy direct from the manufacturers & 23 & $18.4 \%$ \\
\hline & Buy from the supermarket & 4 & $3.2 \%$ \\
\hline & $\begin{array}{l}\text { Buy from informal businesses such as street } \\
\text { vendors, spaza shops }\end{array}$ & 2 & $1.6 \%$ \\
\hline & Buy from a distributor & 3 & $2.4 \%$ \\
\hline & & & \\
\hline & TOTAL & $\mathbf{1 2 5}$ & $\mathbf{1 0 0 \%}$ \\
\hline Number of suppliers & $1-10$ suppliers & 103 & 88.8 \\
\hline & $11-20$ suppliers & 6 & 5.2 \\
\hline & More than 20 suppliers & 2 & 1.7 \\
\hline Missing & TOTAL & 5 & 4.3 \\
\hline & & $\mathbf{1 1 6}$ & $\mathbf{1 0 0 \%}$
\end{tabular}


Table Cont'd

\begin{tabular}{llll} 
*Support & They deliver to the business & 36 & $9.8 \%$ \\
\hline & Supplier charge affordable prices & 101 & $27.4 \%$ \\
\hline They provide sign post & 35 & $9.5 \%$ \\
\hline They provide promotional materials & 50 & $13.6 \%$ \\
\hline We receive discounted prices & 79 & $21.4 \%$ \\
\hline We receive shop equipment & 17 & $4.6 \%$ \\
\hline Supplier offer training & 16 & $4.3 \%$ \\
\hline Supplier provides credit & 24 & $6.5 \%$ \\
\hline Supplier provides trading stock on time & 11 & $3.0 \%$ \\
\hline & & \\
\hline TOTAL & $\mathbf{1 6 9}$ & $\mathbf{1 0 0 \%}$ \\
\hline
\end{tabular}

*Multiple response questions

\section{Challenges influencing independent retailers}

From figure 1 below it can be observed that the challenges influencing the operations of independent retailers in SA are, in order of their impact, financial challenges, followed by marketing-, supplier- and business-related challenges. Finance-related challenges have the biggest influence on independent retailers' operations and include "High business rental costs", "Limited access to finance", "Costs of buying the products are too high" and "High taxation". Marketing challenges represent the next group of challenges that influence independent retailers' operations and include "Competition from other businesses", "Lack of market access", "Lack of demand for our products", "Promoting the products and business" and "Poor sales performance". The third group of challenges, namely, supplier-related challenges, include "Unavailability of affordable suppliers", "High cost of transportation", "Late deliveries", "Uncertain availability of stock from suppliers", "High inventory costs", "Shortage of supplies", "Suppliers are unreliable" and "Lack of trading stock". The findings are consistent with other studies that found finance to be a major threat to independent retailers (Olwawale \& Gware, 2010; Lekhanya, 2010). Lack of access to finance was also reported by Phokwane (2020) and Makhubela (2019) as having a major influence on independent retailers. Makhitha (2016) and Van Scheers (2011) found that marketing is one of the challenges that independent retailers face.

This study found that business-related challenges have the least impact on independent retailers. Business-related challenges ( $\mathrm{n}=32$ ) include "Difficulty finding suitable location for business", "Government regulations", "Lack of guidance on business development", "Shortage of skills" and "Lack of business skills". This finding contradicts findings of existing studies that reported that independent retailers' performance is greatly impacted by a lack of business skills (Blignaut \& Demana, 2002; Das Nair, 2016).

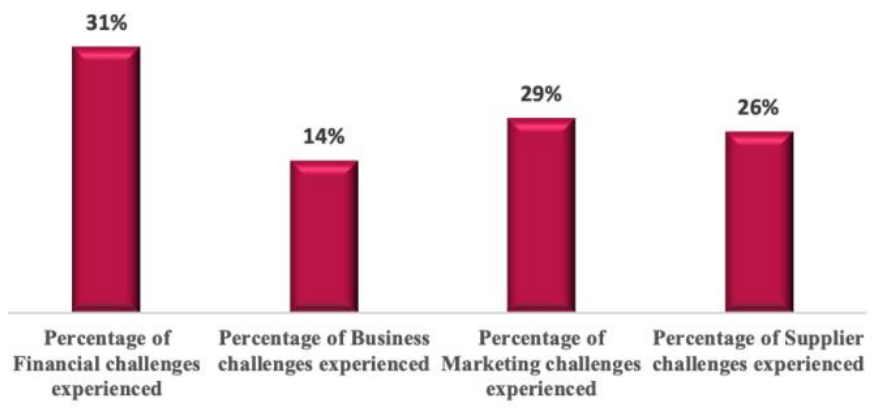

Figure 1: Challenges influencing independent retailers

The demographic factors and the challenges influencing independent retailers

The One-way ANOVA test was used to investigate if the types if challenges facing independent retailers differ across demographics.

\section{Demographics and finance challenges}

The One-way ANOVA test was used to investigate possible significant differences among the education level groups regarding the percentage of financial challenges that they reportedly experience. The test found that education level does not have a significant effect on the percentage of financial challenges experienced by the respondents $(F(4)=0.803, p>05)$. The One-way ANOVA test was used to investigate possible significant differences among the Business operation groups regarding the percentage of financial challenges that they reportedly experience. The test found that maturity level does have a significant effect (at the 5\% level of significance) on the percentage of financial challenges experienced by the respondents $(F(4)=3.45, p<05)$. However, post hoc tests could not find significant difference for any of the pairs of means. The One-way ANOVA test was used to investigate possible significant differences among the number of suppliers groups regarding the percentage of financial challenges that they reportedly 
experience. The test found that maturity level does not have a significant effect on the percentage of financial challenges experienced by the respondents $(\mathrm{F}(2)=1.39, \mathrm{p}>05)$.

\section{Demographic factors and marketing challenges}

The One-way ANOVA test was used to investigate possible significant differences among the education level groups regarding the percentage of marketing challenges that they reportedly experience. The test found that education level does not have a significant effect on the percentage of marketing challenges experienced by the respondents $(F(4)=1.284$, $p>05)$. The One-way ANOVA test was used to investigate possible significant differences among the Business operation groups regarding the percentage of marketing challenges that they reportedly experience. The test found that maturity level does have a significant effect (at the $1 \%$ level of significance) on the percentage of marketing challenges experienced by the respondents $(F(4)=4.074, p<01)$. However, post hoc tests could not find significant difference for any of the pairs of means, except a marginal $(\mathrm{p}=0.055)$ significant difference between the "between 1 to 3 years" group and the "Between 5 and 10 years" group.öThe One-way ANOVA test was used to investigate possible significant differences among the number of suppliers groups regarding the percentage of marketing challenges that they reportedly experience. The test found that maturity level does not have a significant effect on the percentage of marketing challenges experienced by the respondents $(\mathrm{F}(2)=0.574, \mathrm{p}>05)$.

\section{Demographic factors and supplier-related challenges}

The One-way ANOVA test was used to investigate possible significant differences among the education level groups regarding the percentage of supplier challenges that they reportedly experience. The test found that education level does not have a significant effect on the percentage of supplier challenges experienced by the respondents $(F(4)=1.607, p>05)$. The One-way ANOVA test was used to investigate possible significant differences among the Business operation groups regarding the percentage of supplier challenges that they reportedly experience. The test found that maturity level does not have a significant effect on the percentage of supplier challenges experienced by the respondents $(F(4)=0.833, p>05)$. The One-way ANOVA test was used to investigate possible significant differences among the number of suppliers groups regarding the percentage of supplier challenges that they reportedly experience. The test found that maturity level does not have a significant effect on the percentage of supplier challenges experienced by the respondents $(\mathrm{F}(2)=0.265, \mathrm{p}>05)$.

\section{Demographic factors and business-related challenges}

The One-way ANOVA test was used to investigate possible significant differences among the education level groups regarding the percentage of business challenges that they reportedly experience. The test found that education level does not have a significant effect on the percentage of business challenges experienced by the respondents $(F(4)=0.307, p>05)$. The One-way ANOVA test was used to investigate possible significant differences among the Business operation groups regarding the percentage of business challenges that they reportedly experience. The test found that maturity level does have a significant effect (at the 5\% level of significance) on the percentage of business challenges experienced by the respondents $(F(4)=2.74$, $p<05)$. However, post hoc tests could not find significant difference for any of the pairs of means. The One-way ANOVA test was used to investigate possible significant differences among the number of suppliers groups regarding the percentage of business challenges that they reportedly experience. The test found that maturity level does not have a significant effect on the percentage of business challenges experienced by the respondents $(\mathrm{F}(2)=0.845, \mathrm{p}>05)$.

\section{Implications}

Finance-related challenges were found to have the biggest influence on independent retailers, followed by marketing challenges. This finding supports some of the existing findings while contracting other findings.

Since independent retailers lack access to finance, government could play a supporting role by reducing the costs of doing business for independent retailers. It has been proven that there is a lack of governmental support and that available support does not reach all independent retailers (Ladzani \& Netswera, 2009; Rogerson, 2001). Government support should be expended to reach all independent retailers, enabling them to develop and sustain their businesses. Limited access to finance and the costs of doing business are major financial challenges for independent retailers. Independent retailers could reduce the costs of doing business by joining industry associations such as the Spaza Shop Association of South Africa and other cooperatives. For example, foreign-owned independent retailers are highly competitive compared to SA-owned independent retailers because they are members of cooperatives that help with the buying of merchandise through group purchasing, which reduces the costs of purchasing products and assists with inventory management and the running of the businesses (Liedeman et al., 2013). Cooperative purchasing will enable SA-owned independent retailers to source products that might not be available from wholesalers (Liedeman et al., 2013), which will also reduce the level of competition that they face from large businesses and other established independent retailers.

Marketing challenges were also found to have an influence on the operations of independent retailers. These challenges include "Competition from other businesses", "Lack of market access" and "Lack of demand for our products". As already proposed, forming a cooperative and working closely with other independent retailers could help reduce the marketing challenges that independent retailers face. For example, working as a cooperative could reduce competition since independent retailers will be working together. It would also create market access opportunities for independent retailers since buying together would reduce the costs of doing 
business, thus making them more competitive. To overcome challenges related to suppliers, independent retailers could develop long-term and collaborative relationships with their suppliers to ensure that they source products from reliable and supportive suppliers (Makhitha, 2017b). This would ensure that they do not run out of stock and do not have late deliveries.

The challenges influencing independent retailers did not differ across levels of education and the number of suppliers that independent retailers source products from. Significant differences were found across years of operation of businesses in respect of finance-, marketing- and business-related challenges but not in respect of supplier-related challenges. Particularly, businesses that were one to three years old experienced more challenges than businesses that had been in operation for longer than three years. Government should provide more support for start-up businesses so that they can overcome some of the challenges that they experience. The grocery retail market enquiry launched by the Department of Economic Development (2015), for example, is an indication of government's intention to support and sustain independent retailers. The enquiry investigated the nature of competition between large retailers that are expanding to townships and independent retailers to determine if the presence of large retailers are the cause of failure of independent retailers in townships and rural areas.

Independent retailers could also buy directly from manufacturers and not from wholesalers. This would reduce the costs of buying since they might pay less when they buy from manufacturers instead of wholesalers, thus making them to be more competitive against the large retailers that have eroded their market. Buying from wholesalers is one major drawback for independent retailers since they pay higher prices than they would be paying if they bought directly from manufacturers. The development of independent retailers is greatly influenced by high inventory costs, competition from other businesses, the costs of buying and the costs of transportation. Lack of access to finance is also a major challenge. The aspects that are least challenging to local independent retailers are taxation, ineffective marketing and the unavailability of affordable suppliers.

\section{Conclusions}

Finance-related challenges were found to have the biggest influence on independent retailers, followed by marketing challenges. The study targeted independent retailers in Johannesburg, SA. The results cannot be generalised across SA. The finance related, marketing related and business-related challenges influencing independent retailers differed across demographics factors of independent retailers.

Other studies could investigate the challenges influencing independent retailers across the country. Further studies could also determine the support systems that are available to independent retailers in SA and the impact of government support on the operations of independent retailers. There is also a need to determine consumers' attitude towards buying from independent retailers as opposed to buying from large retailers. Future studies could also focus on how ensure that small independent retailers survive and eventually develop into large retailers.

\section{References}

Afande, O.F. (2015). Factors influencing growth of small and microenterprises in Nairobi central business district. Journal of Poverty, Investment and Development, 9(1), 104-139.

Basker, E. and Noel, M. (2013). Competition Challenges in the Supermarket Sector with an Application to Latin American Markets. Report for the World Bank and the Regional Competition Centre for Latin America.

Beck, T \& Demirguc-Kunt, A. (2006). Small and medium-size enterprises: Access to finance as a growth constraint, Journal of Banking \& Finance, 30, 2931-2943.

Bowen, M., Morara, M. \& Mureithi, S. (2009). Management of business challenges among Small and micro enterprises in NairobiKenya, KCA Journal of Business Management, 2(1), 2009.

Breytenbach, A. 2014. Black consumers' shopping patronage and perceptions of the Riverside Mall's attractiveness. PhD thesis. University of Pretoria, Pretoria. Unpublished.

Brink, A.; Cant, M \& Ligthelm, A. (2003). Problems experienced by small businesses in South Africa. A paper for the Small Enterprise Association of Australia and New Zealand 16th Annual Conference, Ballarat, 28 Sept-1 Oct, 28, 1-20.

Chikwekwe T. (2015). Independent retail and grocery shops in Zimbabwe: survival and demise in a crisis and post-crisis era. Journal of Marketing Channels 22, 121-136.

Chiliya, N, Herbst, G. \& Roberts-Lombard, M. (2009). The impact of marketing strategies on profitability of small grocery shops in South African townships, African Journal of business Management, 3 (3), 70-79.

Ciubotariu M.S. (2013). The role of small and medium enterprises in the modern economy and the importance of IFRS application for SMEs. The USV Annals of Economics and Public Administration 13(1), 201-210.

Cooper D.R \& Schindler PS. (2006). Business research methods. 9th ed. New York, NY: McGraw-Hill.

Craig, N.; DeHoratius A \& Raman, A. 2016. The Impact of Supplier Inventory Service Level on Retailer Demand Nathan Working Paper 11-034. [Internet: https://www.hbs.edu/faculty/Publication\%20Files/11-034_95f981a4-388b-40f3-9751fb654b05162e.pdf, downloaded 2021-01-12.]

Cruz-Cunha, M.M. \& Varajao, J. 2011. Innovations in SMEs and Conducting E-Business: Technologies, Trends and Solutions. IGI Global. 
Das Nair R. (2016). Competition in supermarkets: a South African perspective 1. 2nd annual competition and economic regulation (Acer) week, Southern Africa. Centre for Competition, Regulation and Economic Development, University of Johannesburg. Working paper, 11 March.

Das Nair, R \& Chisoro, S. (2015). The expansion of regional supermarket chains: changing models of retailing and the implications for local supplier capabilities in South Africa, Botswana, Zambia, and Zimbabwe. United Nations University world Institute for development Economics Research. WIDER Working Paper 2015/114.

Das Nair, R \& Dube, S.S. (2015). Competition and regulation: competition, barriers to entry and inclusive growth: case study on fruit and veg city. Centre for competition, regulation and economic development, University of Johannesburg. Working paper $9 / 2015$.

Department of Economic Development. (2015).3Grocery retail sector market inquiry terms of reference, October 2015. Report No. 39347. [Internet: http://www.gov.za/sites/www.gov.za/files/ 39347_gen1035.pdf; downloaded 2016-09-15.]

Durham, L. (2011). Opportunities and challenges for South African retailers. Supermarket \& Retailer, 33-35.

Global Agricultural Information Network. 2011. 2010 Annual Retail Food Sector report. South Africa. [Internet: https://gain.fas.usda.gov/Recent\%20GAIN\%20Publications/Retail\%20Foods_Pretoria_South\%20Africa\%2020Republic\%20of_1-5-2011.pdf, downloaded 2017-05-17.]

Gbolagade A, Adesola M.A, \& Oyewale I.O. (2013). Impact of Marketing Strategy on Business Performance A Study of Selected Small and Medium Enterprises (Smes) In Oluyole Local Government, Ibadan, Nigeria. Journal of Business Management, 11(4) 59-66.

Grimsholm, E., \& Poblete, L. (2009). Internal and External factors hampering SME growth - A qualitative case study of SMEs in Thailand. A dissertation submitted in fulfilment of the requirements for the degree of Master in Business Administration: International Management in the Faculty of Social Sciences at the Gotland University.

Hassan, M.U., Qureshi, S.U., Sharif, S. \& Mukhtar, A. (2013). Impact of Marketing Strategy Creativity on Organizational Performance via Marketing Strategy Implementation Effectiveness: Empirical Evidence from Pakistani Organizations, Middle-East Journal of Scientific Research, 16 (2), 264-273.

Hogarth-Scott, S., Watson, K., \& Wilson, N. (1996). Do small businesses have to practice marketing to survive and grow? Marketing Intelligence \& Planning, 14 (1), 6-18.

Italian Trade Agency. (2013). Overview of the South African retail market. ICE-Agenzia per la promozione all'estero e l'internazionalizzazione delle imprese italiane On behalf of Veneto Promozione S.c.p.A, October 2013.

Jena, P.K. (2010). Indian handicrafts in globalization times: An analysis of global-local dynamics. Interdisciplinary Description of Complex Systems, 8(2), 119-137.

Khosa, R.M. \& Kalitanyi, V. (2014). 'Challenges in operating micro-enterprises by African foreign entrepreneurs in Cape Town, South Africa'. Mediterranean journal of social sciences, 5(10): 205-215.

Kongolo, M. (2010). Job creation versus job shedding and the role of SMEs in economic development, African Journal of Business management, 4 (11), 2288-2295.

Ladzani, W. \& Netswera, G. (2009). Support for rural small businesses in Limpopo Province, South Africa, Development Southern Africa, 26(2), 225-239.

Leboea, S.T. 2017. The Factors Influencing SME Failure in South Africa. Dissertation. University of Cape Town. Unpublished.

Lekhanya, L.M. (2010). The Use of Marketing Strategies by Small, Medium and Micro Businesses in Rural KwaZulu-Natal. An unpublished PHD dissertation thesis, Durban University of Technology.

Liedeman R. (2013). Understanding the Internal Dynamics and Organisation of Spaza Shop Operators: A case study of how social networks enable entrepreneurialism among Somali but not South African traders in Delft South, Cape Town, Master's thesis, University of the Western Cape.

Liedeman, R., Charman, A., Piper, L. \& Petersen, L. (2013). Why are foreign-run spaza shops more successful? The rapidly changing spaza sector in South Africa. Sustainable Livelihoods Foundation. Econ3x3.

Ligthelm, A.A. (2008). The impact of shopping mall development on small township retailers, South African Journal of Economic and Management Sciences, 11(1), 37-53.

Lussier, R.N \& Hyder, S. (2016). Why businesses succeed or fail: A study on small businesses in Pakistan. Journal of Entrepreneurship in Emerging Economies, 8(1), 82-100.

Makhitha KM. 2019. Supplier relationship marketing practices and small retailer performance in South Africa. Cogent Business \& Management (2019), 6: 1-17. Online.

Makhitha K.M. (2017a). Supplier selection criteria used by independent retailers in Johannesburg, South Africa. Journal of Business and Retail Management Research, 11(3), 72-84.

Makhitha, K. M. (2017b). The impact of independent retai- lers' relationship marketing practices on perfor- mance. Journal of Contemporary Management, 14,645-673.

Makhitha K.M. (2016). Challenges impacting on small independent retailers' performance in Soweto, Johannesburg in South Africa. Investment Management and Financial Innovations, 13(3), 98-107.

Makhubela, V.F. 2019. The impact of Marketing Communication Strategies on the performance of Small Independent Retailers in Soweto, South Africa. Dissertation. UNISA. Unpublished. 
Makori, A. K. (2013). Challenges and strategies of small and micro enterprises in industrial area of Nairobi, Kenya by a research project submitted in partial fulfilment of the requirements for the award of the degree of master of business administration, University of Nairobi.

Mariotti, S. \& Glackin, C. 2012. Entrepreneurship and Small Business Management. New Jersey: Pearson.

McCartan-Quinn, D. \& Carson, D. (2002). Issues which impact upon marketing in small firm. Small Business Economics 21(2), 201216.

Migiro A \& Ocholla DN. (2005) Information and communication technologies in small and medium scale tourism enterprises in Durban, South Africa. Information Development 21(4), 283-294.

Mnisi, K.L. (2014). Entrepreneurial Support amongst Small and Micro Enterprises in the Greater Giyani Municipality. Dissertation Tshwane University of Technology.

Muhammed, M.Z., Char, A.K., Yasoa, M.R \& Hassan, Z. (2010). Small and Medium Enterprises (SMEs) Competing in the Global Business Environment: A Case of Malaysia. International Business Research, 3(1), 66-75.

Mutandwa, E., Taremwa, N.K \& Tubanambazi, T. (2015). Determinants of business performance of small and medium size enterprises in Rwanda.Journal of developmental entrepreneurship, 20(1), https://doi.org/10.1142/S1084946715500016.

Eijdenberg, L.M \& Borner, D. (2017). The performance of subsistence entrepreneurs in tanzania's informal economy. Journal of Developmental Entrepreneurship, 22(1), DOI: 10.1142/S1084946717500078.

Nieman, G., Hough, J. \& Nieuwenhuizen, C. (2003). Entrepreneurship: A South Africa perspective. Pretoria: Van Schaik.

Olawale, F. \& Garwe, D. (2010). Obstacles to the growth of new SMEs in South Africa: A principal component analysis approach, African Journal of Business Management, 4(5), 729-738.

Ozgener S \& I'raz R. (2006). Customer relationship management in small-medium enterprises: the case of Turkish tourism industry. Tourism Management, 1356-1363.

Pearson, J.N. \& Ellram, L.M. (1995). Supplier selection and evaluation in small versus large electronic firms. Journal of Small Business Management, October, 55-65.

Phaladi, M, \& Thwala, W. 2008. Critical success factor for small and medium sized contractors in North West

province, South Africa. [online]. Available:http://www.academicjournals.

Phokwane, L.C. (2020). Factors influencing marketing strategy formulation for small and medium enterprises in Polokwane. Dissertation. UNISA. Unpublished.

PWC. (2012). South African Retail and Consumer Products Outlook 2012-2016. PWC and Economist Intelligence Unit Report, October 2012. [Internet: (http://www.pwc.co.za/en/assets/pdf/retail-and-consumer-productsoutlook-2012-2016.pdf, downloaded 2016-11-15.]

Radipere, S. \& Van Scheers, L. (2005). Investigating whether a lack of marketing and managerial skills is the main cause of business failure in South Africa, South African Journal of Economics and Management Sciences, 8 (4):402.

Ravhugoni, T. \& M. Ngobese . (2010). Disappearance of Small Independent Retailers in South Africa: The Waterbed and Spiral Effects of Bargaining Power'. [Internet: http://www.compcom.co.za/wp-content/uploads/2014/09/Disappearance-of-SmallIndependent-Retailers-in-South-Africafinal.pdf, downloaded 2016-07-01.]

Reardon T, Timmer CP, Barrett CB \& Berdegue J. (2003). The rise of supermarkets in Africa, Asia and Latin America. American Journal of Agricultural Economics 85, 1140-1146.

Rogerson CM. (2001). Growing the SMME manufacturing economy in South Africa: evidence from Gauteng province. Journal of Contemporary Management 19(2), 267-291.

Soke, B.V. 2014. The application of internet marketing by small, medium and micro enterprise in Soweto. Masters dissertation. Tshwane University of Technology. Pretoria. Unpublished.

Standard Bank. (2014). 5-key-trends-affecting-the-retail-market-in-2014. $\quad$ Accessed fromhttp://bizconnect.standardbank.co.za/sector-news/retail-wholesale/south-africa-5-key-trends-affecting-theretailmarket-in-2014.aspx, accessed on 01/07/2016.

Sustinalytics. (2012). Building a Sustainable South African Food Retail Sector, Issues for Responsible Investors, [Internet: http://www.sustainalytics.com/sites/default/files/uploads/BuildingSustainableSAFoodRetailSector_August2012.pdf, downloaded 2016-08-10/\}

Thomas White. (2011). Emerging Market Spotlight Retail in South Africa: Making an Impression. [Internet: https://www.thomaswhite.com/pdf/emerging-markets-spotlight-south-africa-consumer-goods-july-2011.pdf, downloaded 2017-07-1.]

Teixeir, A.C \& Sharifu, H.A. (2017). Female entrepreneurship and access to bank loans in Tanzania: a double-hurdle model approach, Journal of Developmental Entrepreneurship, 22(3), https://doi.org/10.1142/S1084946717500194.

W\&R Seta. (2011). Independent Food Retailers in the Republic of South Africa. Can they Ensure Sustainability in an Evolving Retail Landscape? [Internet: http://www.wrseta.org.za/downloads/ILDP/Imitha\%20Final.pdf, downloaded 2016-08-10.]

Van Eeden, S., Viviers, S. \&Venter, D. (2003). A comparative study of selected problems encounterd by small businesses in the Nelson Mandela, Cape Town and Egoli metropoles. Management Dynamics, 12 (3), 13-23.

Van Scheers, L. (2011). SMEs' marketing skills challenges in South Africa, African Journal of Business management, 5(13), 50485056. 
Wanjohi, S. \& Mugambi, F. 2017. 'Factors influencing the choice of a credit program by small and micro enterprises owners in Kenya: A case study of Thika town'. International Journal of Entrepreneurship, 1(2): 17-32.

Wiklunda,B. \& Shepherd, D. (2005). Entrepreneurial orientation and small business performance: a configurational approach Johan. Journal of Business Venturing 20, 71 - 91.

Publisher's Note: SSBFNET stays neutral with regard to jurisdictional claims in published maps and institutional affiliations.

\section{(a) (1)}

(C) 2021 by the authors. Licensee SSBFNET, Istanbul, Turkey. This article is an open access article distributed under the terms and conditions of the Creative Commons Attribution (CC BY) license (http://creativecommons.org/licenses/by/4.0/).

International Journal of Research in Business and Social Science (2147-4478) by SSBFNET is licensed under a Creative Commons Attribution 4.0 International License. 